\title{
CORRELATION OF CARCASS MEAT CONTENT WITH DEVELOPMENT OF THE REPRODUCTIVE SYSTEM IN SEXUALLY IMMATURE GILTS
}

\author{
Hanna JANKOWIAK ${ }^{1 *}$, Wojciech KAPELAŃSKI ${ }^{1}$, Maria BOCIAN ${ }^{1}$, Angéla SOLTÉsZ ${ }^{2}$ \\ and Péter BALOGH ${ }^{2}$ \\ ${ }^{1}$ Department of Pig Breeding and Horses, Faculty of Animal Breeding and Biology, \\ UTP University of Science and Technology in Bydgoszcz, Mazowiecka 28, \\ 85-084 Bydgoszcz, Poland; ${ }^{2}$ Department of Research Methodology and Statistics, \\ University of Debrecen, Debrecen, Hungary
}

(Received 24 November 2015; accepted 4 May 2016)

\begin{abstract}
This study evaluated the correlation of carcass meat content with the development of the reproductive system in sexually immature gilts of Polish Large White (PLW) and Polish Landrace (PL) breeds. The results, obtained from three groups (I, II, III) of gilts differing in lean meat percentage, indicate an effect on fattening and slaughtering traits as well as on the morphometric characteristics of the uterus. There were statistically significant differences in the values of fattening and slaughtering traits in the groups of gilts tested. Studies on the relationship between morphometric characteristics of the reproductive system and carcass meat content showed that there was a correlation between the weight of the uterus with and without the broad ligament and the meat content of the carcass. The weight of the uterus was higher $(\mathrm{P} \leq 0.05)$ in gilts with lower meat content. The negative influence of high gilt meatiness on development of the reproductive system was more pronounced in PLW gilts.
\end{abstract}

Key words: Gilts, lean meat content, morphometric traits, pigs, uterine development

One of the most significant objectives of pig production is to obtain numerous litters and wean as many healthy piglets as possible. A major issue having significant economic impact on the improvement of pig reproduction is the unexplainable loss of fertilised oocytes during the first month of pregnancy (Tuggle et al., 2000). The attempts made to improve the reproductive capacity of pigs are therefore focused on the increase of litter size. Litter enlargement, if only by a single piglet, would increase the income earned by pig producers. An example of this is the selection aimed at improving ovulation (Foxcroft et al., 2006, 2009) or increasing litter size (Knoll et al., 2002; Milligan et al., 2002; Rosendo et al., 2007). At the same time, reproduction performance traits are

"Corresponding author; E-mail: jankowiak@utp.edu.pl; Phone: 0048 (52) 374-9748 
known to be characterised by a low coefficient of heritability, while their extent is decisively determined by the environment. Therefore, the efficiency of selection for reproductive traits is generally unsatisfactory.

Animals intended for reproduction should have adequate body weight and fatness, enabling the long-term maintenance of high reproduction performance (Rekiel and Więcek, 2002). Selection aimed at improving the meatiness and reducing the fatness of gilts may lead to a belated attainment of sexual maturity, resulting in a delay of the first farrowing (Mucha et al., 2010). The negative correlations between excessive muscularity and the reproduction performance of gilts and sows have been demonstrated in numerous studies (Rydhmer et al., 1994; Tummaruk et al., 2007; Stančić et al., 2011).

The aim of this work was to assess the impact of muscularity degree on growth and development of the reproductive system in gilts prior to attaining sexual maturity.

\section{Materials and methods}

The experiment was carried out on a total of 200 Polish Large White (PLW) and Polish Landrace (PL) gilts, 100 animals of each breed. The selection of experimental gilts and the conditions of their nutrition and maintenance were consistent with the methodology developed for the Pig Testing Station (Różycki and Tyra, 2010). Routine examination covered growth rate of female pigs from a body weight of 30 to $100 \mathrm{~kg}$. The animals were kept in individual pens with straw bedding. Gilts were fed a feed mixture containing $13.00 \mathrm{MJ} / \mathrm{kg}$ metabolisable energy and $12.8 \%$ crude protein ad libitum. They were slaughtered after they had achieved a body weight of approximately $100 \pm 0.6 \mathrm{~kg}$. The entire reproductive system was removed from the carcasses and evaluated. Twenty-four $\mathrm{h}$ after slaughter, the cooled carcasses were measured to determine fatness and muscularity level. The research methods were approved by the Local Research Committee (No. 21/2008).

The reproductive system was evaluated on the basis of the following measurements: weight of the uterus with and without the broad ligament, length of the uterine cervix and the uterine horns (right and left), size (height, length and width) and volume of the ovaries. In addition, the volume of the uterine lumen was measured by filling the uterus with physiological saline and then measuring the volume of the liquid using the method described by Kapelański et al. (2013). The ratio between the weight of the uterus without the broad ligament and the length of the uterine horns $(\mathrm{g} / \mathrm{cm})$ was calculated as a measure roughly characterising the thickness of the uterine wall.

The data were analysed separately for the two breeds and statistically compared. Based upon the meat content of the carcass (expressed in percent) the gilts were assigned to three groups. Group I consisted of gilts with a carcass meat 
content below 59\% $(\mathrm{n}=70)$, Group II comprised gilts with a carcass meat content ranging from 59 to $62 \%(\mathrm{n}=76)$, and Group III consisted of gilts having a carcass meat content above $62 \%(n=54)$. The gilts' allocation to a particular group was based on the value of normal distribution (Gauss curve). The results were analysed statistically and the data were given as arithmetic means \pm standard deviations. To estimate the variability and reciprocal connections between morphometric parameters of the reproductive system of PLW and PL gilts, a two-factor analysis of variance was conducted according to the following model:

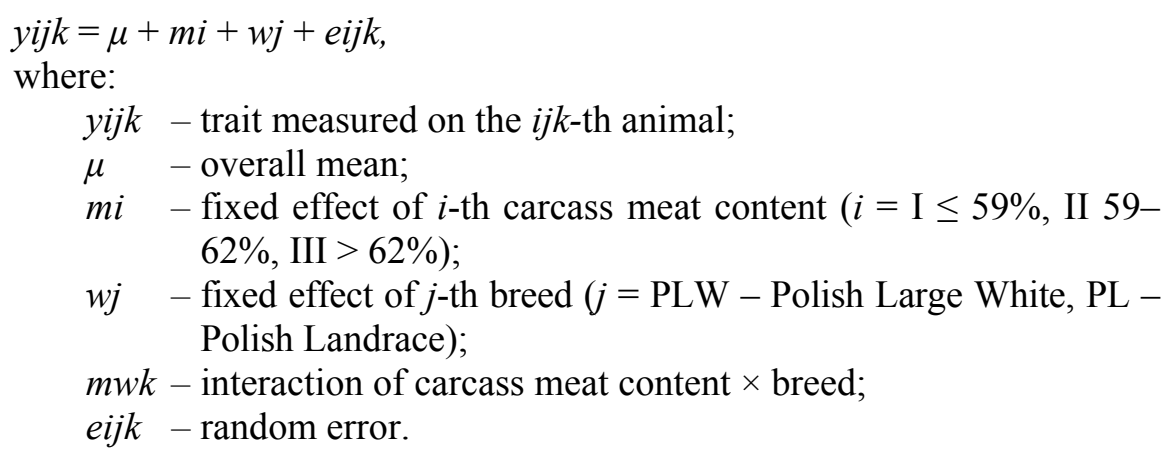

The mean values were compared by the LSD test. In addition, linear relationships between morphometric traits of the gilts' reproductive system, within the breed of origin, were calculated as xy - Pearson correlation coefficients. The STATISTICA 8 PL (StatSoft, Inc., 2008) computer software was used for the calculations.

\section{Results}

The characteristics of fattening and slaughter performance are shown in Table 1. The two-factor analysis of variance did not show any significant interactions between carcass meat content and the breed. As regards differences in the muscularity of gilts, the most numerous animal group within the PLW breed was Group I, while that within the PL breed was Group II. The slaughtering age of the gilts differed: PL gilts were slightly younger when slaughtered compared to PLW gilts; a significant difference with regard to that trait was demonstrated only within Group I $(\mathrm{P} \leq 0.05)$. Gilts from Group I showed a higher growth rate $(961 \mathrm{~g})$ than those from Group III $(911 \mathrm{~g})(\mathrm{P} \leq 0.05)$. The tested gilts of both breeds were characterised by high meatiness and relatively low fatness. The meat content of the carcass increased as gilt fatness decreased.

The uterine morphometric characteristics of gilts of the two breeds as a function of carcass muscularity are presented in Table 2 . The average values of uterine weight with and without the broad ligament were significantly higher in Group I than in Group III $(\mathrm{P} \leq 0.05)$. The length of the uterine horns in the PLW 
breed was significantly lower among gilts with the highest carcass meat content (Group I; P $\leq 0.05$ ). On the other hand, the volume of the uterine lumen significantly differed between the PL and PLW breeds in Group I. Pigs of the PL breed were characterised by a higher volume of uterine lumen $(\mathrm{P} \leq 0.05)$.

\section{Table 1}

Characteristics of fattening and slaughter performance depending on the lean meat percentage of gilts

\begin{tabular}{|c|c|c|c|c|}
\hline \multirow[b]{2}{*}{ Item } & \multirow[b]{2}{*}{ Breed } & \multicolumn{3}{|c|}{ Carcass meat content, $\%$} \\
\hline & & $\begin{array}{c}\mathrm{I} \\
<59\end{array}$ & $\begin{array}{c}\text { II } \\
59-62\end{array}$ & $\begin{array}{c}\text { III } \\
>62\end{array}$ \\
\hline \multirow[t]{3}{*}{ Number, $\mathrm{n}$} & PLW & 40 & 37 & 23 \\
\hline & PL & 30 & 39 & 31 \\
\hline & Total & 70 & 76 & 54 \\
\hline \multirow[t]{3}{*}{ Age at slaughter, days } & PLW & $170.75^{x} \pm 19.55$ & $170.62 \pm 18.10$ & $172.78 \pm 15.73$ \\
\hline & PL & $161.67^{y} \pm 14.70$ & $166.59 \pm 19.31$ & $166.59 \pm 19.31$ \\
\hline & Total & $166.86 \pm 18.09$ & $168.55 \pm 18.71$ & $171.00 \pm 17.67$ \\
\hline \multirow[t]{3}{*}{ Daily gain, g/day } & PLW & $941 \pm 120$ & $908 \pm 104$ & $918 \pm 118$ \\
\hline & PL & $987 \pm 111$ & $943 \pm 161$ & $906 \pm 110$ \\
\hline & Total & $961^{\mathrm{a}} \pm 118$ & $926 \pm 137$ & $911^{\mathrm{b}} \pm 112$ \\
\hline \multirow[t]{3}{*}{ Feed efficiency, $\mathrm{kg} / \mathrm{kg}$} & PLW & $2.67 \pm 0.43$ & $2.65 \pm 0.35$ & $2.52 \pm 0.36$ \\
\hline & PL & $2.58 \pm 0.37$ & $2.53 \pm 0.37$ & $2.50 \pm 0.37$ \\
\hline & Total & $2.63 \pm 0.40$ & $2.59 \pm 0.37$ & $2.51 \pm 0.36$ \\
\hline \multirow[t]{3}{*}{ Average backfat thickness, cm } & PLW & $15.99^{\mathrm{A}} \pm 0.40$ & $13.77^{\mathrm{B}} \pm 0.19$ & $11.51^{\mathrm{C}} \pm 0.20$ \\
\hline & PL & $15.75^{\mathrm{A}} \pm 0.27$ & $13.61^{\mathrm{B}} \pm 0.22$ & $11.66^{C} \pm 0.22$ \\
\hline & Total & $15.89^{\mathrm{A}} \pm 0.35$ & $13.69^{\mathrm{B}} \pm 0.20$ & $11.60^{\mathrm{C}} \pm 0.21$ \\
\hline \multirow[t]{3}{*}{ Carcass meat content, $\%$} & PLW & $56.76^{\mathrm{A}} \pm 2.27$ & $60.52^{\mathrm{B}} \pm 0.95$ & $63.84^{C} \pm 1.72$ \\
\hline & PL & $56.99^{\mathrm{A}} \pm 1.85$ & $60.23^{\mathrm{B}} \pm 0.90$ & $63.56^{\mathrm{C}} \pm 1.33$ \\
\hline & Total & $56.86^{\mathrm{A}} \pm 2.09$ & $60.37^{\mathrm{B}} \pm 0.93$ & $63.68^{C} \pm 1.50$ \\
\hline
\end{tabular}

PLW - Polish Large White; PL - Polish Landrace; Statistical significance in rows: ${ }^{\mathrm{A}, \mathrm{B}, \mathrm{C}} \mathrm{P} \leq 0.01$, ${ }^{\mathrm{a}, \mathrm{b}} \mathrm{P} \leq 0.05$; in columns: ${ }^{\mathrm{x}, \mathrm{P}} \mathrm{P} \leq 0.05$

The characteristics of the oviducts and ovaries are shown in Table 3. No significant differences between the analysed animal groups were demonstrated with regard to these characteristics. The sole characteristic observed was that oviducts tended to become longer with a decrease in carcass meat content both in the PLW and the PL breeds. The weight, volume and dimensions (height, length and width) of the ovaries were determined. The weight and volume of ovaries in gilts with a carcass meat content below 59\% (Group I) were slightly higher compared to the corresponding values obtained for gilts with higher leanness (Groups II and III). However, the differences were not statistically significant. 


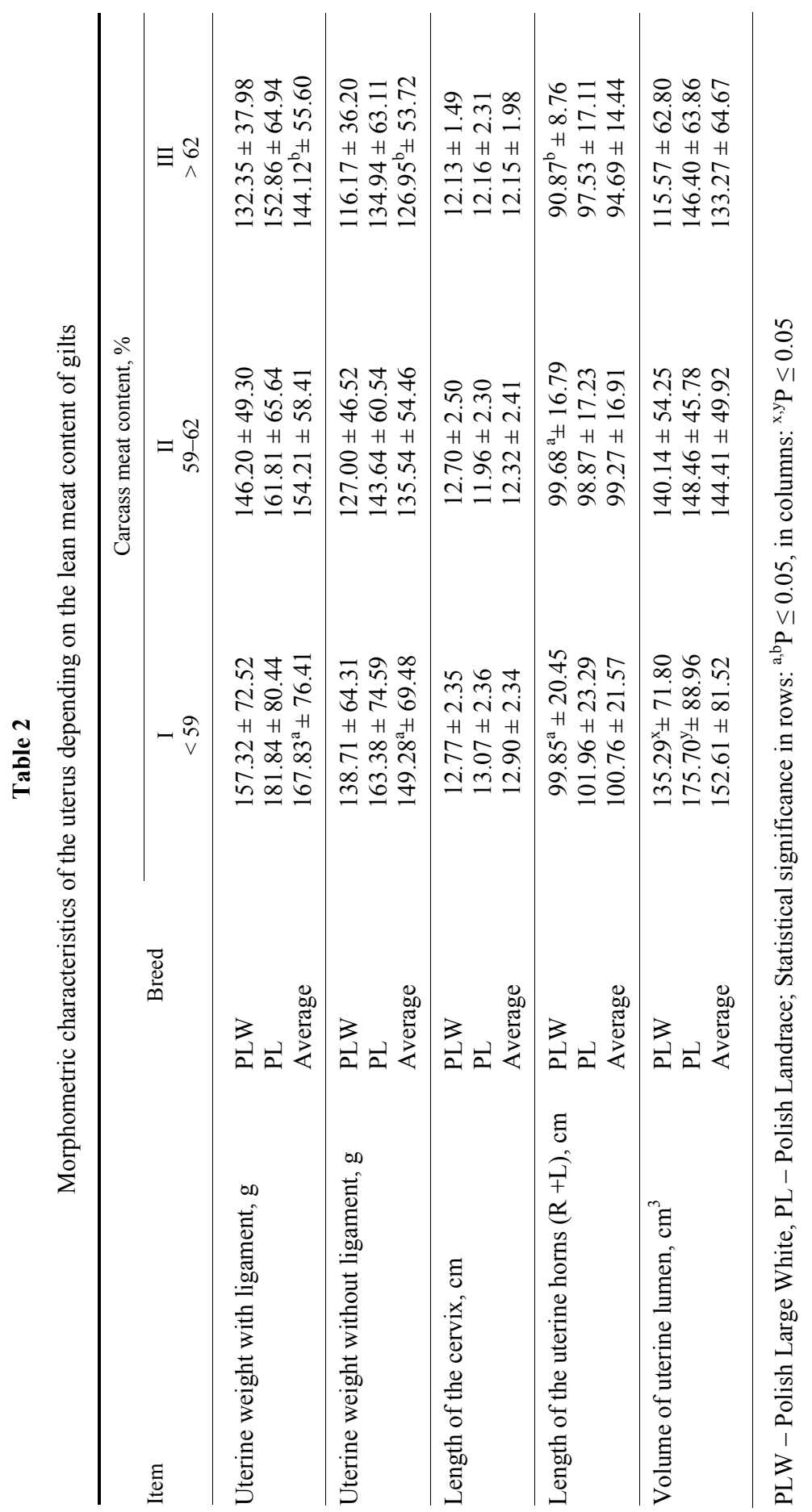




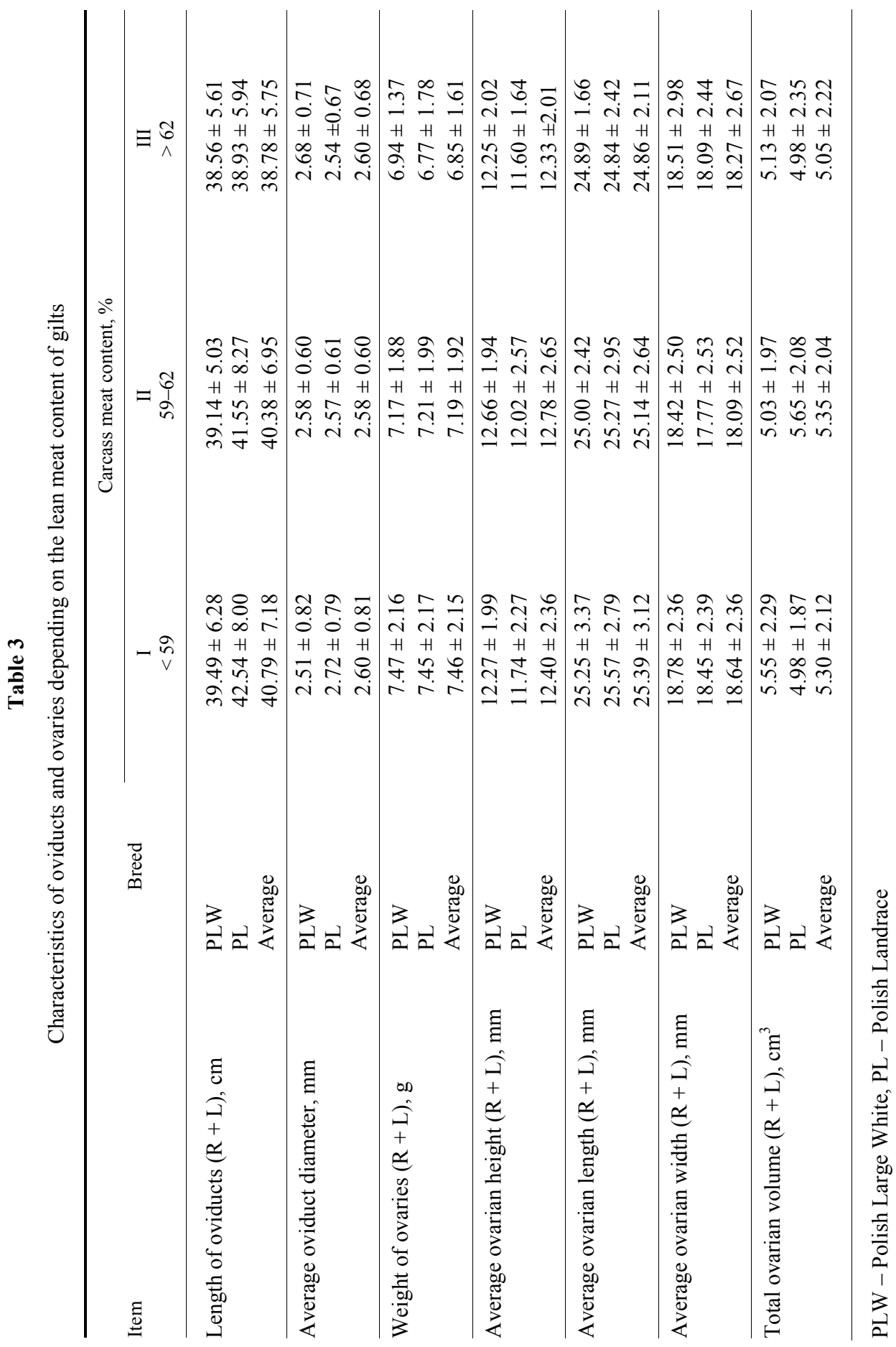


Correlations between gilt carcass meat content and morphometric characteristics of the reproductive system are presented in Table 4. Overall, higher correlation coefficients and more statistically significant correlations were found in PLW gilts. It should be noted that the calculated correlation coefficients had negative values with regard to muscularity. This might confirm the suggestions reported in the literature that high meatiness in gilts has a negative effect on reproductive performance.

Table 4

Coefficients of correlation between carcass meat content and selected morphometric characteristics of the reproductive system in Polish Large White (PLW) and Polish Landrace (PL) gilts

\begin{tabular}{|c|c|c|c|}
\hline Morphometric traits & PLW & PL & Total \\
\hline Uterine weight with ligament, $g$ & $-0.307^{\mathrm{xx}}$ & -0.133 & $-0.200^{\mathrm{x}}$ \\
\hline Uterine weight without ligament, $\mathrm{g}$ & $-0.312^{\mathrm{xx}}$ & -0.139 & $-0.202^{\mathrm{xx}}$ \\
\hline Length of the cervix, $\mathrm{cm}$ & -0.112 & -0.142 & -0.130 \\
\hline Length of the uterine horns $(\mathrm{R}+\mathrm{L}), \mathrm{cm}$ & $-0.226^{\mathrm{x}}$ & -0.067 & $-0.142^{\mathrm{x}}$ \\
\hline Weight/length of uterine horns, $\mathrm{g} / \mathrm{cm}$ & $-0.328^{\mathrm{xx}}$ & -0.069 & $-0.184^{\mathrm{xx}}$ \\
\hline Volume of uterine lumen, $\mathrm{cm}^{3}$ & -0.182 & -0.114 & -0.131 \\
\hline Length of oviducts $(\mathrm{R}+\mathrm{L}), \mathrm{cm}$ & -0.093 & -0.139 & -0.102 \\
\hline Weight of ovaries $(\mathrm{R}+\mathrm{L}), \mathrm{g}$ & -0.127 & -0.183 & $-0.155^{\mathrm{x}}$ \\
\hline Total ovarian volume $(\mathrm{R}+\mathrm{L}), \mathrm{cm}^{3}$ & $-0.212^{\mathrm{x}}$ & -0.054 & -0.138 \\
\hline
\end{tabular}

PLW - Polish Large White; PL - Polish Landrace. Statistical significance: ${ }^{\mathrm{xx}} \mathrm{P} \leq 0.01,{ }^{\mathrm{x}} \mathrm{P} \leq 0.05$

\section{Discussion}

Selection for protein deposition, conducted intensively in recent years, determines the metabolic and hormonal condition of the body (Herpin et al., 1993). According to Beltranena et al. (1993), in gilts with a high genetic potential there is only a minor correlation between growth rate and fatness versus early attainment of sexual maturity and the development of ovaries. According to them, these traits are primarily affected by the inborn variable pulsatile secretion of luteinising hormone (LH). The PLW and PL gilt populations compared in this study did not differ in growth rate measured as daily gain, feed efficiency, and average backfat thickness. However, the weights of the uterus with and without ligament were higher in the less muscled gilts of the PL than in those of the PLW breed. Similarly, the higher volume of uterine lumen in the less meaty PL gilts predicts better reproductive performance compared to PLW gilts.

An adequately developed reproductive system with a well-developed uterus, ovaries and oviducts ensures the production of a high number of corpora lutea, the implantation of embryos and the survival of many fetuses. This in turn determines the number of piglets in a litter (Szostak and Sarzyńska, 2005). However, there is a risk that the building of a large amount of muscle tissue in the 
body occurs at the expense of the development of other organs, including organs of the reproductive system. Negative correlations between the improvement of feed conversion efficiency and the increase in meat content were demonstrated by Eliasson et al. (1991) and by Kerr and Cameron (1995). The studies conducted by Rekiel and Więcek (2002) showed that sows with higher meat content gave birth to less numerous litters. Similarly, significant negative correlations between meatiness and reproductive performance have been demonstrated by Matysiak et al. (2010) in PLW gilts. The largest number of piglets were delivered and reared up to the 21st day of life by gilts with the smallest loin eye area. Moreover, the highest number of stillbirths occurred in gilts with the highest lean meat content. Statistically significant negative correlations between meatiness (determined based on the height of the loin eye area and carcass meat percentage) and the total number of piglets born alive and the number of piglets both on the 21st day of life and on the day of weaning were demonstrated by Kawęcka et al. (2009). Kerr and Cameron (1995) indicated that selection for lean growth on either an ad libitum or a restricted feeding regime did not significantly affect reproductive performance, while animals in lines with high lean feed conversion ratio or low daily feed intake had reduced reproductive performance. The results obtained by Bečková et al. (2005) on a group of Landrace gilts suggest that reproductive performance is more determined by growth rate and backfat thickness than by meat content. On the other hand, according to other researchers there is no correlation between meatiness and reproductive performance traits such as fertility, the number of piglets born alive in a litter or the number of piglets reared (Čechová et al., 2000; Bocian et al., 2010). The negative associations between high lean meat content of gilts and their reproductive efficiency are presumably due to the unfavourable relation of high growth rate and body protein accretion versus puberty attainment. Booth et al. (1994) called attention to the significant effect of feeding intensity on metabolic and reproductive status. According to Rydhmer et al. (1994), gilts with a higher genetic capacity for growth had a lower genetic capacity for oestrous traits than those with a lower growth rate. The possible effect of an adequate feeding regime and nutritional manipulation on metabolic and reproductive function deserves special attention (Booth et al., 1994; Rozeboom et al., 1995; Klindt et al., 1999; Ji et al., 2005).

In conclusion, the results of this study indicate the influence of carcass meat content on morphometric characteristics of the reproductive system in sexually immature gilts. It has also been demonstrated that high meat content of the carcass has a negative effect on uterine weight, length of the uterine horns, and ovarian volume in the PLW breed. The results obtained in this research may have practical importance in gilt selection and preparation for reproduction. 


\section{Acknowledgement}

This study was supported by the State Committee for Scientific Research of Poland, Grant No. PB 0800/B/P01/2009/37.

\section{References}

Beltranena, E., Aherne, F. X. and Foxcroft, G. R. (1993): Innate variability in sexual development irrespective of body fatness in gilts. J. Anim. Sci. 71, 471-480.

Bečková, R., Danek, P., Václavková, E. and Rozkot, M. (2005): Influence of growth rate, backfat thickness and meatiness on reproduction efficiency in Landrace gilts. Czech J. Anim. Sci. 50, 535-544.

Bocian, M., Jankowiak, H., Grajewska, S., Gajdošová, L., Kapelańska, J. and Kapelański, W. (2010): Evaluation of breeding and reproductive value of Polish Large White and Polish Landrace sows from the Kujawy-Pomerania Region [in Polish]. Roczniki Nauk. Zoot. 37, 137-144.

Booth, P. J., Craigon, J. and Foxcroft, G. R. (1994): Nutritional manipulation of growth and metabolic and reproductive status in prepubertal gilts. J. Anim. Sci. 72, 2415-2424.

Čechová, M., Tvrdon, Z., Bečková, R. and Mikule, V. (2000): Analysis of the influence of lean meat percentage on the reproductive traits of the White Improved and Landrace sows. Biul. Nauk. 7, 51-57.

Eliasson, L., Rydhmer, L., Einarsson, S. and Andersson, K. (1991): Relationships between puberty and production traits in the gilt. 1. Age at puberty. Anim. Reprod. Sci. 25, 143-154.

Foxcroft, G. R., Dixon, W. T., Dyck, M. K., Novak, S., Harding, J. C. S. and Almeida, F. C. R. L. (2009): Prenatal programming of postnatal development in the pig. In: RodriguezMartinez, H., Vallet, J. L. and Ziecik, A. J. (eds) Control of Pig Reproduction VIII. Nottingham University Press, Nottingham, U. K. pp. 213-233.

Foxcroft, G. R., Dixon, W. T., Novak, S., Putman, C. T., Town, S. C. and Vinsky, M. D. (2006): The biological basis for prenatal programming of postnatal performance in pigs. J. Anim. Sci. 84, Supplement, E105-112.

Herpin, P., Le Dividich, J. and Amaral, N. (1993): Effect of selection for lean tissue growth on body composition and physiological state of the pig at birth. J. Anim. Sci. 71, 2645-2653.

Ji, F., Wu, G., Blanton, Jr. J. R. and Kim, S. W. (2005): Changes in weight and composition in various tissues of pregnant gilts and their nutritional implications. J. Anim. Sci. 83, 366-375.

Kapelański, W., Jankowiak, H., Bocian, M., Grajewska, S., Dybała, J. and Zmudzińska, A. (2013): Morphometric characteristics of the reproductive system in Polish Large White and Polish Landrace gilts at $100 \mathrm{~kg}$ body weight. Annals Anim. Sci. 13, 45-53.

Kawęcka, M., Matysiak, B., Kamyczek, M. and Delikator, B. (2009): Relationships between growth, fatness and meatiness traits in gilts and their subsequent reproductive performance. Annals Anim. Sci. 9, 249-258.

Kerr, J. C. and Cameron, N. D. (1995): Reproductive performance of pigs selected for components of efficient lean growth. Anim. Sci. 60, 281-290.

Klindt, J., Yen, J. T. and Christenson, R. K. (1999): Effect of prepubertal feeding regimen on reproductive development of gilts. J. Anim. Sci. 77, 1968-1976.

Knoll, E. F., Leenhouwers, J. I. and Van Der Lende, T. (2002): Genetic aspects of piglets survival. Live Prod. Sci. 78, 47-55.

Matysiak, B., Kawęcka, M., Pietruszka, A., Jacyno, E. and Kołodziej-Skalska, A. (2010): Reproduction performance of sows depending on level of meatiness during first service. Acta Sci. Pol. Zoot. 9, 153-160. 
Milligan, B. N., Fraser, D. and Kramer, D. L. (2002): Within-litter birth weight variation in the domestic pig and its relation to pre-weaning survival, weight gain, and variation in weaning weights. Live Prod. Sci. 76, 181-191.

Mucha, A., Orzechowska, B., Tyra, M. and Koska, M. (2010): Relationships between performance test of gilts and their subsequent fitness, muscling and fertility [in Polish]. Rocz. Nauk. Pol. Tow. Zoot. 6, 59-64.

Rekiel, A. and Więcek, J. (2002): The effect of body weight, backfat thickness and LD muscle height at first breeding in gilts on their reproductive performance over three subsequent parities [in Polish]. Pr. Mat. Zoot., Zesz. Spec. 13, 131-138.

Rosendo, A., Canario, L., Druet, T., Gogue, J. and Bidanel, J. P. (2007): Correlated responses of pre- and postweaning growth and backfat thickness to six generations of selection for ovulation rate or prenatal survival in French Large White pigs. J. Anim. Sci. 85, 3209-3217.

Rozeboom, D. W., Pettigrew, J. E., Moser, R. L., Cornelius, S. G. and el Kandelgy, S. M. (1995): Body composition of gilts at puberty. J. Anim. Sci. 73, 2524-2531.

Różycki, M. and Tyra, M. (2010): Methodology for tested fattening and slaughter value at Pig Testing Station (SKURTCh) [in Polish]. IZ PIB, Kraków, XXVIII, 93-117.

Rydhmer, L., Eliasson-Selling, L., Johansson, K., Stern, S. and Andersson, K. (1994): A genetic study of estrus symptoms at puberty and their relationship to growth and leanness in gilts. J. Anim. Sci. 72, 1964-1970.

Stančić, I., Stančić, B., Božić, A., Anderson, R., Harvey, R. and Gvozdić, D. (2011): Ovarian activity and uterus organometry in delayed puberty gilts. Theriogenology 76, 1022-1026.

StatSoft, Inc. (2008): STATISTICA (data analysis software system), version 8.0.

Szostak, B. and Sarzyńska, J. (2005): Characteristics of reproductive organs and potential fertility of gilts at different age [in Polish]. Rocz. Nauk. Pol. Tow. Zoot. 2, 343-349.

Tuggle, C. K., Malchenko, S., Woods, R., Whitworth, K., Green, J. A., Prather, R., Fitzsimmons, C. J., Roberts, C. A., Casavant, T. and Soares, M. B. (2000): Development of new placental and fetal expressed sequence tags (EST) for gene discovery in pig reproduction. 2000 ISU Swine Research Report Breeding/Physiology, Iowa Pork Industry Center, Iowa State University, Ames, Iowa, USA. pp. 104-107.

Tummaruk, P., Tantasuparuk, W., Techakumphu, M. and Kunavongkrit, A. (2007): Age, body weight and backfat thickness at first observed oestrus in crossbred Landrace $\times$ Yorkshire gilts, seasonal variations and their influence on subsequence reproductive performance. Anim. Repr. Sci. 99, 167-181. 